\title{
THE EFFECTIVENESS OF GREEN TEA AND MORINGA TEA ON THE LEVEL OF DYSMENORRHEA PAIN IN ADOLESCENTS
}

\author{
Intani Ega Rarassari') Ribkha Itha Idhayanti²) Siti Chunaeni3) \\ Email : ribkhaitha@gmail.com
}

\begin{abstract}
Background: According to the World Health Organization (WHO) in Indonesia, the incidence of dysmenorrhea is $55 \%$ in productive age, $15 \%$ of them complain of limited activity due to dysmenorrhea. Forms the results of a preliminary study conducted, it's showed that the results of interviews with young women showed that $60 \%$ of adolescents experienced dysmenorrhea, $20 \%$ sometimes, and $20 \%$ did not experience dysmenorrhea. Dysmenorrhea is a problem for teenagers in carrying out their daily activities, especially in the learning process.

The purpose of this study was to determine the effectiveness of green tea and moringa tea on reducing the level of dysmenorrhea pain in adolescents

Methods: This design of research uses a quasi-experimental approach with a two-group pretest-posttest design approach. The population 40 and sample 32 respondents with an accidental sampling technique.

Results: In this study, it was found that moringa is effective in reducing the pain of dysmenorrhea. With the results of the Mann-Whitney test $p$-value $=0.031$. moringa tea more effective than green tea

Conclusion: . In this study, it is hoped that adolescents can optimize non-pharmacological therapy by consuming moringa tea to reduce dysmenorrhea

Keyword: Dismenorrhea Pain, Adolescent
\end{abstract}

1,2,3 Department of Midwifery Magelang, Poltekkes Kemenkes Semarang, Indonesia

Jl. Perintis Kemerdekaan 143 Magelang, Jawa Tengah, Indonesia

Received: July 23, 2021; Revised: August 27, 2021; Accepted: September 28, 2021

Background. Adolescence is the process of growth and development both physically, psychologically, and intellectually. (Kemenkes $\mathrm{RI}, 2017)$. Adolescence is an important time in the course of human life because it becomes the transition from childhood to adulthood and is often referred to as puberty. Changes experienced by adolescents include changes physically and psychologically. (Rosyida 2019).

Physical changes in adolescents are characterized by changes in physical appearance and physiological function or maturity of sexual organs. Adolescents will experience changes in primary sexual characteristics and secondary sexual characteristics gradually. At this time the hormone will affect the maturation of the uterus, breast growth, and teenagers will experience menstruation. Dysmenorrhea is a common medical problem in women of reproductive age. Dysmenorrhea is abdominal pain that comes from uterine cramps and often occurs during the menstruation period. Dysmenorrhea can be classified into primary and secondary dysmenorrhea. Dysmenorrhea premiere is menstrual pain that is not caused by a disease. Primary menstrual pain will appear from the first menstruation and will recover on its own over time and primary menstrual pain is still relatively normal. While secondary menstrual pain is pain that arises due to disease, or persistent abnormalities such as uterine infections. (Rosyida 2019)

In some teenagers can experience complaints of dizziness, nausea, vomiting, headaches, lower abdominal pain, pelvic pain, and even fainting. Although dysmenorrhea is a common problem, it can interfere with daily activities in adolescents if the condition is allowed to continue. Dysmenorrhea can be suffering for those who experience it. Dysmenorrhea can be one of the causes of symptoms of endometritis, then it will have an impact on the decline of women's health, quality of life, and fertility so it needs attention at the time of dysmenorrhea. (Pramardika and Fitriana 2019) 
The prevalence of dysmenorrhea in Indonesia is $62.25 \%$, consisting of $54.8 \%$ primary dysmenorrhea and $9.36 \%$ secondary dysmenorrhea. (Hamdiyah and Sukarta 2019). According to the World Health Organization (WHO) in Indonesia, the incidence of dysmenorrhea is $55 \%$ in the productive age, $15 \%$ of whom complain of limited activity due to dysmenorrhea. Census results conducted by the Central Statistics Agency in Central Java showed that young women made up $11.78 \%$ of the total population of $32,548,687$. Dismenore as many as $1,518,867$ people.

Dysmenorrhea pain is experienced by many teenagers, but many also ignore it without making proper handling efforts. Dysmenorrhea pain can be treated with pharmacological and non-pharmacological therapies. Pain that must be overcome immediately makes some teenagers more often use anti-pain drugs or in a pharmacological way. The nature of the drug only relieves pain and will cause dependence on the drug.

Based on the above background researchers are interested in researching "The Effectiveness of Green Tea and Moringa Tea Against Dysmenorrhea Pain Levels In Adolescents".

Methods. Quasi-Experimental Design is a research design used in this study with the design of Two Group Pretest-Postest Design research conducted using two groups that were given interventions. $\mathrm{O} 1$ is called pretest and after the $\mathrm{O} 2$ experiment, it is called postest. In this study, the number of young women in Mlipak was 40 people who had dysmenorrhea.

The population 40 in the study was sample 32 respondents with an accidental sampling technique In this study, a sample of 16 respondents in the intervention group was given green tea and 16 respondents in the intervention group were given moringa tea

\section{Result and Discussion.}

\section{Effect of Desminore Pain Level Before and} After Green Tea Intervention

The decrease mean level of pain before and after drinking green tea is 13.31 , Wilcoxon test was conducted and it can be known that there are 16 respondents are experiencing a decrease in the level of dysmenorrhea pain (negative rank), 0 respondents experienced an increase in dysmenorrhea pain (positive rank), and there were 0 respondents with permanent pain (ties). Based on the value of Z-score = $3,660 \mathrm{~b}$ indicates that there was a decrease in the level of dysmenorrhea pain by 3.6 times after the intervention of moringa tea. Asymp results. Sig (2-tailed) $=0.000$, so it can be concluded that there is a significant difference between the level of dysmenorrhea pain before and after the green tea intervention.

The decrease mean level of pain before and after drinking moringa tea is 19.69. It is known that the data is normal distribution due to value pretest $=0.073$ and value posttest $=0.095$ (pvalue>0.05). The dependent T-Test with value pretest and posttest intervention with moringa tea is $0.000(p \leq 0.05)$, so it can be concluded that there is a significant difference between the level of dysmenorrhea pain before and after moringa tea intervention. Moringa tea more effective than green tea

\section{Effect of Desminore Pain Levels Before and After Intervention}

Decreased dysmenorrhea pain occurs because green tea contains polyphenols that have anti-inflammatory activity that will inhibit prostaglandin production so that dysmenorrhea pain is reduced. Green tea also provides a relaxing effect that will stimulate endorphin hormones in the body. Endorphins are released by the pituitary gland as a form of response from pain, then bind to opioid receptors that inhibit the release of neurotransmitters that affect pain impulses to the brain. Endorphin hormone as a natural tranquilizer and equivalent to the effects of morphine will help the body become more positive and more relaxed. With the body become relaxed the pain of dysmenorrhea will be reduced. (Idhayanti Ribkha Itha, Munayarokh, and Mundarti 2019)

The results of this study are in line with research conducted by (Mulyadi Astriana \& Debby Chintia 2019) on the Effect of Green Tea Consumption On Dysmenorrhea Pain in Young Women who stated that there is an effect of green tea consumption on The The decrease level of pain before and after drinking green tea is 13.31, dysmenorrhea pain in adolescent girls in SMA N 1 Agung Way Kanan Regency with an average intensity of dysmenorrhea pain before green tea consumption of 7.67 with a standard deviation of 2.42. While the average intensity of dysmenorrhea pain after consuming green tea amounted to 4.67 with a standard deviation of 1.93 and value $=0.000$. 
Decreased pain of dysmenorrhea after the administration of moringa tea can occur because moringa contains flavonoid compounds. Flavonoids act as analgesics whose mechanism of work inhibits the work of cyclooxygenase enzymes. Form the inhibition of the enzyme cyclooxygenase that will play a role in reducing prostaglandin production to reduce the pain of dysmenorrhea. (Tamimi, De Queljoe, and Siampa 2020)

In addition to flavonoid content, moringa natural compounds that can reduce pain such as caffeoylquinic, kaempferol, and quercetin, in abundant amounts as natural COX-2 inhibitors that will block the ENZYME COX-2 so that prostaglandin production is hampered.

Research conducted by (Hamdiyah and Sukarta 2019) on the Effect of Moringa Oleifera Leaves (Moringa Oleifera Leaves) On The Decline of Dysmenorrhea In Adolescents Girls Anemia In Aisyiyah Orphanage Sidrap Regency is in line with research conducted by researchers. According to the results of the study, value $=0.000$ in the intervention group and value $=0.041$ in the control group. Stating that there is an effect of moringa leaf tea on the decrease in dysmenorrhea pain in adolescent girls who are anemic.

Judging from the content, both have different contents where green tea contains polyphenols that have anti-inflammatory activity that will inhibit prostaglandin production so that dysmenorrhea pain is reduced. (Mulyadi Astriana \& Debby Chintia 2019).

While moringa tea contains flavonoids that act as analgesics whose mechanism of work inhibits the work of cyclooxygenase enzymes. Form the inhibition of the enzyme cyclooxygenase will play a role in reducing prostaglandin production to reduce the pain of dysmenorrhea. (Tamimi, De Queljoe, and Siampa 2020).

Based on research conducted by (Rosalie Benita 2018) on the Effect of Green Tea Consumption of Dipp on Decreased Pain Intensity in UKRIDA Medical Students Class of 2016 with Primary Dysmenorrhea. Based on the results of the test Wilcoxon obtained value $=0.000$ (value $\leq 0.05$ ) with Zscore $=6,321$ stated that there was a decrease in the intensity of dysmenorrhea pain after consuming green teabags in respondents.

This research is in line with research conducted by (Tamimi, De Queljoe, and Siampa 2020) about The Analgesic Effect Test of Moringa Leaf Ethanol Extract. In Male Rats Galur Wistar (Rattus norvegicus) states that moringa leaves have an effect on the reduction of pain with the results of the One Way ANOVA test obtained a value of value $=0.044$ (value $\leq$ 0.05).

Conclusion and Suggestions. There was an effect on the level of dysmenorrhea pain in adolescents before and after green tea interventions seen from the results of the analysis using Wilcoxon test results because the data did not distribute normally with a value of $z=-3.660 \mathrm{~b}$ showed that there was a decrease in the level of dysmenorrhea pain by 3.6 times after the intervention of moringa tea and Asymph.Sig (2-tailed) $=0.000$ (value $\leq 0.05)$. There is an effect on the level of dysmenorrhea pain in adolescents before and after moringa tea intervention saw from the results of the analysis using the results of the T-Test Dependent, mean, and standard deviation decreased value pretest moringa tea $=4.56$ with standard deviation $\pm 1,094$ with value posttest $=2.69$ with standard deviation $\pm 1,302$ with value 0.000 (value $\leq 0.05$ ).

The statistical test results using MannWhitney are pvalue $=0.031$ (value $\leq 0.05$ ), so it can be stated that the administration of moringa tea intervention against dysmenorrhea pain levels in adolescents is more effective than by using green tea intervention. The results of this study showed differences in the effectiveness of green tea and moringa tea with the mean rank of dysmenorrhea pain levels in the green tea intervention group were lower judging from the frequency distribution of dysmenorrhea pain levels before and after being given green tea and moringa tea. The results of statistical tests using Mann-Whitney found value $=0.031$ (value $\leq 0.05)$, with a mean rank of green tea $=$ 13.31 and moringa tea $=19.69$ so it can be stated that moringa tea against dysmenorrhea pain levels in adolescents is more effective than green tea intervention.

\section{References}

Hamdiyah, and Asmah Sukarta (2019) 'Pengaruh Pemberian Teh Daun Kelor (Moringa Oleifera Leaves) Terhadap Penurunan Dismenore Pada Remaja Putri Anemia Di Panti Asuhan Sejahtera Aisyiyah Kabupaten Sidrap'. Journal Between Obstetrics 2(4): 61-70. 
Idhayanti Ribkha Itha, Munayarokh, and Mundarti (2019). 'Terapi Dalam Mengatasi Disminore Primer Pada Remaja Putri'. Jendela Inovasi Daerah Vol II(2): 32-42.

Mulyadi Astriana \& Debby Chintia (2019). 'Effect of Green Tea Consumption On Dysmenorrhea Pain in Young Women: Journal of Pharmacy Malahayati 2(1): 122-28.

Mulyadi Astriana \& Debby Chintia (2019). 'Efektivitas Senam Dismenore Sebagai Terapi Alternatif Menurunkan Tingkat Nyeri Haid Tinjauan Sistematis Penelitian.' Journal of Pharmacy Malahayati 2(1): 122-28.

Pramardika, Dhito Dwi, and Fitriana (2019). Panduan Penaganan Dismenore.
Ribkha Itha Idhayanti, Purwaningsih, Yani, Arfiana, and. (2020). 'Acupressure Technique to Reduce Dysmenorrhea.' Midwifery and Nursing Research 2(2): 74-78.

Rosalie Benita, Aslim Setiawan \& Elena Maria Irene (2018). 'Pengaruh Konsumsi Teh Hijau Celup Terhadap Penurunan Intensitas Nyeri Pada Mahasiswi Fakultas Kedokteran UKRIDA Angkatan 2016 Dengan Dismenore Primer.' Artikel Penelitian. 10 of 10.

Rosyida, Desta Ayu Cahya (2019). 'Pengaruh Konsumsi Teh Hijau Celup Terhadap Penurunan Intensitas Nyeri Pada Mahasiswi Fakultas Kedokteran UKRIDA Angkatan 2016 